\title{
New and poorly known Oriental Chrysomelidae (Coleoptera)
}

\section{Новые и малоизвестные Ориентальные Chrysomelidae (Coleoptera)}

\author{
L.N. Medvedev \\ М.H. Медведев
}

Institute for Problems of Ecology and Evolution, Russian Academy of Sciences, Leninsky prospect 33, Moscow 119071, Russia. ИнститутпроблемэкологиииэволюцииРАН, Ленинскийпроспект 33, Москва 119071, Россия.

KEY WORDS: Chrysomelidae, new species, new localities, China, Vietnam, Malaysia.

КЛЮЧЕВЫЕ СЛОВА: Chrysomelidae, новые виды, новые местонахождения, Китай, Вьетнам, Малайзия.

ABSTRACT. A new genus (Apophylana gen.n.) and 10 new species (Aoria humeralis, Colaspoides cilicornis, C. kelantana, Pyrrhalta shaanxiana, Apophylana thoracica, Clerotilia fulvicornis, Hoplasoma kelantani, Cneorane malayana, Bhamoina nigripes, Sphaeroderma scalei spp.n.) are described. New localities are recorded for the 4 species.

РЕЗЮМЕ. Описываются новый род (Apophylana gen.n.) и 10 новых для науки видов (Aoria humeralis, Colaspoides cilicornis, C. kelantana, Pyrrhalta shaanxiana, Apophylana thoracica, Clerotilia fulvicornis, Hoplasoma kelantani, Cneorane malayana, Bhamoina nigripes, Sphaeroderma scalei spp.n.). Для 4 видов указаны новые местонахождения.

\section{Introduction}

Thanks to amiability of Dr. Matthias Hartmann I had a good opportunity to study new materials from Erfurt Museum, collected in Northern Vietnam, Thailand and China. As a result of this study 1 genus and 10 species are described as new for science, a few species are firstly recorded for China and Malaysia.

Next abbreviations are used for depository places of new species:

MNE - Erfurt Museum, Erfurt, BRD.

LM - author's collection, Moscow, Russia.

Taxonomical part

\section{Eumolpinae}

Aoria (s.str.) humeralis Medvedev, sp.n. Fig. 1.

MATERIAL. Holotype: N-Vietnam, Lao Cai Prov., Hoang Lien NP, Tram Ton, 22²1'197" N, 10346’513” E, 13-16.V.2015, 1800-2050 m, leg. A. Scale (NME). A single specimen is in rather bad state.
DESCRIPTION. Black, 2 basal antennal segments and humeral area of elytra reddish fulvous, maxillar palpi fulvous with black apical segments, upperside with white hairs.

Head densely punctate and microsculptured, anterior margin of clypeus arcuate, supraantennal swelling feeble and poorly distinct. Antennae broken, except two basal segments. Prothorax 1.4 times as wide as long, broadest in middle, entirely unmargined on sides, evenly convex, densely punctured, with narrow, flat and micro-sculptured interspaces. Scutellum elongate with rounded apex, punctured. Elytra 1.5 times as long as wide, surface shining, strongly punctate and partly arranged in irregular rows, especially on innerside, hairs long, erect and not arranged in rows. Length of body 5.5 mm.

DIAGNOSIS. Near A. nigromarginata L. Medvedev, 2012 from China, differs with black body, except red fulvous humeral area and irregular rows of punctures on innerside of elytra.

\section{Colaspoides kelantana Medvedev, sp.n.} Fig. 3.

MATERIAL. Holotype, $\sigma^{7}$ : Malaysia W, Kelantan, $40 \mathrm{~km} \mathrm{~N}$ of Gua Musang, Gunung Benangkat Kampong Riek, 1100 m, 15.V. 2017, leg. Petr Cechovsky (NME). tennae.

DESCRIPTION. Metallic green with entirely black an-

Body elongate ovate, 1.7 times Clypeus triangular with straight anterior margin, finely and densely punctate, microsculptured, frons and vertex practically impunctate, with deep longitudinal groove in middle. Antennae reach middle of elytra, proportions of segments are as 10-6-11-10-12-15-1414-14 (2 apical antennal segments absent). Prothorax 1.6 times as wide as long, broadest before base, with lateral margins not explanate, with moderately dense punctures and rather large smooth interspaces. Elytra 1.25 times as long as wide, with moderately strong and uniform punctures, including sides and apices, interspaces larger than punctures, flat or feebly convex. Propleurae shining, with a few punctures. All femora not toothed, posterior femora without brush. Aedeagus (Fig. 3) distinctly widened to triangular apex. Length $4.2 \mathrm{~mm}$.

DIAGNOSIS. This species belongs to species group 5 [Medvedev, 2003] and might be placed near C. nigricollis Jacoby, 1884 and C. cechovskyi L. Medvedev, 2016 (all three

How to cite this article: Medvedev L.N. 2019. New and poorly known Oriental Chrysomelidae (Coleoptera) // Russian Entomol. J. Vol.28. No.2. P.165 -168. doi: 10.15298/rusentj.28.2.08 
species have entirely black antennae), but differs, except details of sculpture of head and prothorax, with form of aedeagus, very distinctly widened to apex, while both other species have parallel-sided aedeagus.

DERIVATIO NOMINIS. A name is connected with region of species distribution.

\section{Colaspoides ciliaticornis Medvedev, sp.n.}

Figs 4-5.

MATERIAL. Holotype, $0^{7}$ : N-Vietnam, Thai Ngugen Prov.,

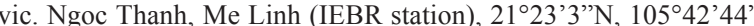
E, $6080 \mathrm{~m}, 12 . \mathrm{V} .2012$, leg. A. Scale (NME)

DESCRIPTION. Entirely fulvous.

Body elongate ovate. Head impunctate, clypeus trapeziform, vertex rather flat, with longitudinal furrow in middle. Antennae with erect hairs on segments 3-7, antennal segments are as 10-4-5-9-11-11-11-11 (next segments absent). Prothorax twice as wide as long, broadest at base, surface convex, shining, finely and very sparsely punctate. Scutellum short triangular, finely punctate. Elytra twice as long as wide, surface densely and moderately strong punctate, with interspaces not microsculptured. Basal ventral sternite with tubercle near hind margin. Posterior tibiae not modified. Segment
1 of fore tarsus enlarged, elongate and narrowed to apex. Aedeagus very complicate and deeply grooved on underside (Figs 4-5). Length of body $5.6 \mathrm{~mm}$.

DIAGNOSIS. Near C. seticornis L. Medvedev, 2003 and especially C. pilicornis Lefevre, 1882, but differs with very complicate structure of aedeagus.

\section{Galerucinae}

Pyrrhalta shaanxiana Medvedev, sp.n. Fig. 6.

MATERIAL. Holotype, $0^{7}$ : China, Shaanxi prov., Hua Shan peak env., $100 \mathrm{~km}$ E of Xian, 1722.VI.1991, Z. Kejval lgt (NME).

DESCRIPTION. Fulvous, labrum, antennae except 3 basal segments, knees and tarsi black, prothorax in middle and scutellum darkened, pubescence of upperside light.

Body elongate, slightly widened to behind. Head distinctly narrower than prothorax at anterior and, clypeus convex, triangular, frontal tubercles narrow, transverse and punctate, vertex strongly and densely punctate, with microsculptured interspaces. Antennae almost reach middle of elytra, proportions of segments are as 6-5-8-8-8-8-8-8-8-8-10. Prothorax 2.1 times as wide as long, broadest in middle, side margin rounded,

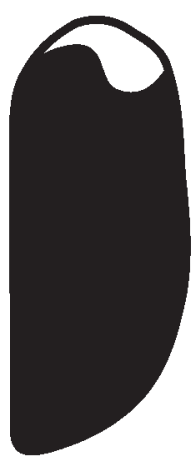

1

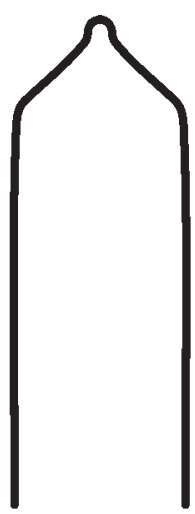

7

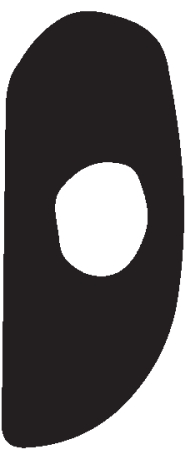

2

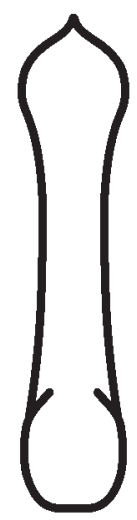

3

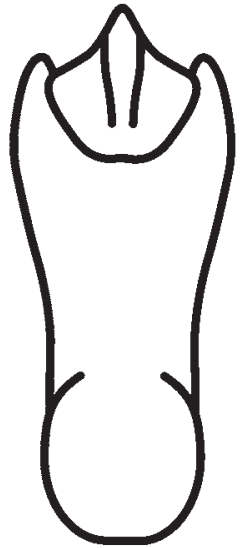

4

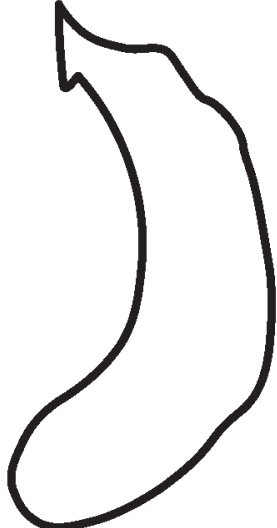

5

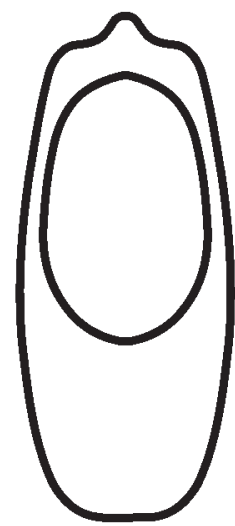

6

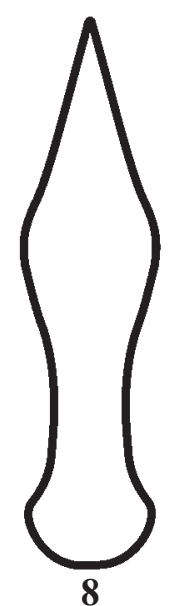

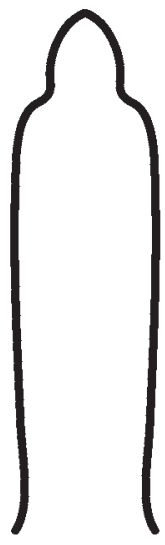

9

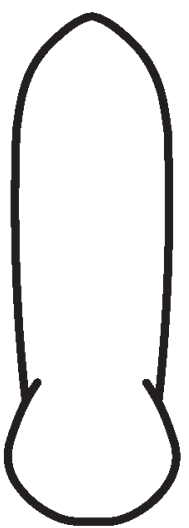

10

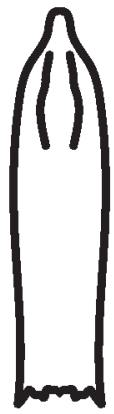

11

Figs 1-11. Chrysomelidae spp.n., details: 1 - Aoria humeralis; 2, 11 - Sphaeroderma scalei; 3 - Colaspoides kelantana; 4-5 C. cilicornis; 6 - Pyrrhalta shaanxiana; 7 - Clerotilia fulvicornis; 8 - Hoplasoma kelantani, 9 - Cneorane malayana; 10 - Bhamoina nigripes; 1-2 - elytral pattern; 3-11 - aedeagus; 3-4, 6-11 - ventral view; 5 - lateral view.

Рис. 1-11. Chrysomelidae, spp.n., детали строения: 1 - Aoria humeralis; 2, 11 - Sphaeroderma scalei; 3 - Colaspoides kelantana; 4-5 - C. cilicornis; 6 - Pyrrhalta shaanxiana; 7 - Clerotilia fulvicornis; 8 - Hoplasoma kelantani, 9 - Cneorane malayana; $10-$ Bhamoina nigripes; 1-2 - окраска надкрылий; 3-11 - эдеагус; 3-4, 6-11 - снизу; 5 - сбоку. 
surface very densely punctate with narrow and convex interspaces, with large lateral impressions and another comparatively small near anterior margin. Scutellum longer than broad, with rounded apex, strongly punctate. Elytra 1.55 times as long as wide, slightly widened to behind, surface very densely punctate, with longitudinal impressed line behind middle and near lateral margin. Aedeagus with truncate apex toothed in middle (Fig. 6). Length of body $7.1 \mathrm{~mm}$.

DIAGNOSIS. Near P. angulaticornis Gressitt and Kimoto, 1963 , but body larger, prothorax arcuate at sides, elytra with a single impressed line near side margin, aedeagus practically symmetrical, with truncate apex.

\section{Apophylana Medvedev, gen.n.}

TYPE SPECIES: Apophylana thoracica sp.n.

DESCRIPTION. Body elongate. Antennal insertions behind anterior margins of eyes. Frontal tubercles subovate, divided from each other. Vertex strongly and densely punctate. Antennae nitidiform. Prothorax strongly transverse, surface densely punctate and shortly pubescent, with shining, smooth and sparsely punctate convexity alonganterior margin, interrupted in middle. Elytra parallel-sided with rounded apices, very densely punctate, but without any distinct pubescence. Epipleurae narrowed in basal third, but distinct to apex. Anterior coxal cavities open. Claws toothed. Hind legs and abdomen absent.

DIAGNOSIS. Near Apophylia Chevrolat, 1842, differs with structure of prothorax and not pubescent elytra.

DERIVATIO NOMINIS. A name is a combination from the generic name Apophylia.

\section{Apophylana thoracica Medvedev, sp.n.}

MATERIAL. Holotype (sex not clear): N-Vietnam, Ninh Binh Prov., Cuc Phuong NP, 20¹7'572” N, 10540’052” E, 270 m, 22 24.V.2015, leg. A. Scale (NME).

DESCRIPTION. Fulvous; vertex, antennal segments 411 convexity on prothorax, scutellum, apices of femora, tibiae and tarsi black, elytra dark metallic green.

Head not pubescent. Antennae almost reach middle of elytra, proportions of segments are as 12-7-9-9-9-9-8-8-8-810. Prothorax 1.8 times as wide as long, broadest in anterior third, with rounded side margin. Scutellum broadly triangular, finely punctate, not pubescent. Elytra 1.8 times as long as wide, surface feebly convex, with very feeble ridge from humerus to apex, more distinct behind middle. Length of body $4 \mathrm{~mm}$

\section{Clerotilia fulvicollis Medvedev, sp.n.}

Fig. 7.

MATERIAL. Holotype, $\sigma^{7}$ : China- Sichuan prov., Dail Dafolohut Forest near Dail, $110 \mathrm{~km}$ W of Chongdu, 21-22.VI.1993, leg. M. Tryzna (NME). Paratypes: same locality and date, 3 90 (NME, 1 ex. - LM).

DESCRIPTION. Fulvous, head dark metallic blue, antennae piceous or fulvous, scutellum piceous, elytra metallic blue.

Head distinctly punctate on vertex, frontal tubercles triangular, convex and impunctate. Antennae of male reach apical slope of elytra, proportions of segments are as 5-3-4-98-8-8-8-9-9-11, segments 510 about 56 times as long as wide. Prothorax twice as wide as long, broadest near middle, feebly convex, finely and sparsely punctate. Scutellum triangular with rounded apex, impunctate. Elytra 1.55 times as long as wide, surface very densely punctate, with very narrow shining interspaces, without basal convexity. Segment 1 of fore and mid tarsi not widened in male. Aedeagus - Fig. 7. Length of male $4.4 \mathrm{~mm}$, of females $4.5-4.7 \mathrm{~mm}$.
DIAGNOSIS. Resembles C. sichuanica Lopatin, 2002, but differs with fulvous prothorax and rather short and broad aedeagus.

\section{Hoplasoma kelantana Medvedev, sp.n.} Fig. 8 .

MATERIAL. Holotype, ơ: Malaysia W., Kelantan, $40 \mathrm{~km}$ N of Gua Musang Gunnung Berangkat Kampong Riek; 1100 m, 15.V.8.VI.2017, Petr Cechovsky lgt. (NME). Paratypes: same locality and date, 2 + $(\mathrm{NME}, \mathrm{LM})$.

DESCRIPTION. Fulvous; labrum, underside, anterior tibiae, tarsi and base of femora, mid and hind legs black.

Body elongate, shining. Head impunctate, frontal tubercles subquadrate, vertex grooved in middle. Antennae of male reach apical slope of elytra, proportions of segments are as 62-7-7-7-7-6-6-6-7-7, segments 5-11 about 5-6 times as long as wide. Prothorax 1.6 times as wide as long, with deep transverse impression, finely and very sparsely punctate, with microsculptured interspaces. Scutellum triangular with rounded apex, impunctate, microsculptured. Elytra about 1.6 times as long as wide, finely and very densely punctate, with microsculptured interspaces,. Tarsal segment 1 of all legs narrow and elongate. Abdomen without processes. Aedeagus - Fig. 8. Length of body $8.3-8.4 \mathrm{~mm}$.

DIAGNOSIS. Near H. majorina Laboissiere, 1929 from China and Indochina, differs in having black labrum and legs as well as very unusual aedeagus.

\section{Cneorane malayana Medvedev, sp.n.} Fig. 9.

MATERIAL. Holotype, ơ: Malaysia W., Kelantan, $40 \mathrm{~km} \mathrm{~N}$ of Gua Musang Berangkat Kampong Riek; 1100 m, 15.V.-8.VI.2017, Petr Cechovsky lgt. (NME).

DESCRIPTION. Male: head, prothorax, scutellum, mesosternum and all femora red, antennae, metasternum, abdomen, tibiae and tarsi black, elytra metallic blue.

Head impunctate, frontal tubercles subquadrate. Antennae reach apical third of elytra, proportions of segments are as 9-5-8-10-10-10-10-10-10-10-12, segment 9 about 3 times as long as wide. Prothorax 1.7 times as wide as long, broadest in anterior third, surface evenly convex, very finely and sparsely punctate. Scutellum trapeziform with rounded apex, shining and impunctate. Elytra 1.4 times as wide as long, parallelsided, without basal convexity, shining, with moderately dense and strong punctures, not arranged in the distinct rows. Segment 1 of anterior and mid tarsi distinctly widened. Aedeagus - Fig. 9.

Length of body $5.6 \mathrm{~mm}$.

DIAGNOSIS. Resembles C. tibialis Chujo, 1966 from Nepal and North India, but differs with quite different form of aedeagus.

\section{Alticinae}

\section{Bhamoina nigripes Medvedev, sp.n.}

$$
\text { Fig. } 10 .
$$

MATERIAL. Holotype, O': SW-China, Sichuan prov., Abazhou: Nanping: Juizhaigou, 2000 m, 8-13.VI.1991 (NME). Paratypes: same locality and date, $4 \sigma^{\top} \sigma^{\top}, 2$ 우 (NME, 2 ex.LM).

DESCRIPTION. Reddish fulvous, antennal segments 411 and legs black.

Body short ovate, 1.4 times as long as wide. Head impunctate, clypeus ridged, frontal tubercles subquadrate, touch each other, vertex grooved in middle. Antennae reach apical slope of elytra, proportions of segments are as 9-5-78-9-8-8-8-7-7-11, segment 9 about 3 times as long as wide. 
Prothorax 1.8 times as wide as long, broadest before base, finely and very sparsely punctate. Scutellum triangular, impunctate. Elytra 1.1 times as long as wide, with feeble humeral tubercle, confusedly and not densely punctate. Segment 1 of all tarsi widened in male, a little longer than broad. Aedeagus - Fig. 10. Length of male $4.6-5.0 \mathrm{~mm}$, of female $4.7-5.1 \mathrm{~mm}$.

DIAGNOSIS. Differs well from Bh. varipes Jacoby, 1894, which has entirely fulvous legs, short antennae, reaching only humeral area of elytra, and very densely punctate prothorax.

\section{Sphaeroderma scalei Medvedev, sp.n.} Figs 2, 11.

MATERIAL. Holotype, $0^{7}$ : N-Vietnam, Cao Bang Prov., vic. Vin Den, Nai Pia Oac Nature Res., 22 $33^{\prime} 53^{\prime \prime} N$, 105 $52^{\prime} 53^{\prime \prime}$ E, 900-1300 m, 06-10.V.2013, leg. A. Scale (NME).

DESCRIPTION. Dark red, antennal segments 411, tibiae and tarsi black, each elytron with ovate fulvous spot in middle.

Body short ovate, 1.2 times as long as wide. Head very finely punctate, frontal tubercles sharp, obliquely placed. Antannae reach middle of elytra, proportions of segments are as 12 12-6-5-7-9-9-9-10-10-11-14. Prothorax 1.7 times as wide as long, broadest near middle, surface finely and rather sparsely punctate, without microsculpture. Scutellum triangular with rounded apex, impunctate. Elytra as wide as long, with dense and moderately strong punctures, partly regular on sides. Segment 1 of fore and mid tarsi widened in male, as long as wide. Aedeagus - Fig. 11. Length of body $3.7 \mathrm{~mm}$.

DIAGNOSIS. Near S. flavoplagiatum Jacoby 1896, widely distributed in Indochina and Indonesia, differs in color of upperside and form of aedeagus.
New localities

Kanarella unicolor Jacoby, 1898

MATERIAL. China: S. Yunnan (Xischuangbanna), $37 \mathrm{~km} \mathrm{NW}$ Jinghong, vic. Cuo Men Shon, $22^{\circ} 14^{\prime} 48^{\prime \prime} \mathrm{N}, 100^{\circ} 36^{\prime} 22^{\prime \prime} \mathrm{E}, 1080 \mathrm{~m}$, 01.VI.2008, pollinator AM, leg. L.Meng, 1 ex. (NME).

REMARK. Was known from India, Nepal and Indochina, firstly found in China.

\section{Laosixantha apicata L.Medvedev}

MATERIAL. Malaysia W., Kelantan, $90 \mathrm{~km} \mathrm{~N}$ of Gua Musang Gunung Basar, Kampong Kubur Datu; 1700 m, 10.IV.5.V.2017, Petr Cechovsky lgt., 1 ex. (NME).

REMARK. Was known from Thailand, firstly recorded for Malaysia.

Nonarthra birmanica (Jacoby, 1892)

MATERIAL. Malaysia W., Kelantan, $40 \mathrm{~km}$ N of Gua Musang Berangkat Kampong Riek; 1100 m, 15.V.8.VI.2017, Petr Cechovsky lgt., 1 ex. (NME).

REMARK. Was known from Nepal, India, Myanmar, Vietnam, firstly found in Malaysia.

Hesperella violaceipennis L.Medvedev, 1995

MATERIAL. Malaysia, pen[insula] Pulau Lang Kawi, 7 wells waterfall, 6²2'45” N, 99॰40’19” E, $70 \mathrm{~m}, 1725$.VI.2017, leg. A.Scale, 1 ex. (NME).

REMARK. Was described from Thailand, firstly found in Malaysia.

\section{Reference}

Medvedev L.N. 2003 (2004). Revision of the genus Colaspoides Laporte (Chrysomelidae, Eumolpinae) from continental Asia // Russian Entomological Journal. Vol.12. No.3. P.257-297. 